\title{
Lessons for the Modern Campaign from the University of Virginia
}

Received (in revised form) July 24, 2002

\section{Donald Hasseltine}

Donald A. Hasseltine is the Vice President of Advancement at Colby-Sawyer College in New London, New Hampshire. Dr. Hasseltine's prior experience includes advancement roles at the University of Virginia, Georgetown University, and New England College. His research interests include history of higher education fund raising, higher education/corporate partnerships, and organizational development. Dr. Hasseltine holds a doctorate from the University of Virginia in Higher Education Administration and has worked in the advancement field for 13 years.

\begin{abstract}
This article chronicles the University of Virginia's first capital campaign and provides historical perspective into the evolution of higher education fund raising. It examines the important strategic components of effective capital campaigning, including goal-setting methods, the effect of national economic trends, the significance of the quiet phase, and the influence of institutional leadership. The first capital campaign of the University of Virginia offers reassurance that modern campaign techniques are firmly grounded in principles and techniques based on lessons of the past. It also demonstrates that future campaign success will require the same commitment to developing improved and more sophisticated approaches to capital campaigning.
\end{abstract}

\footnotetext{
Author's Contact Address:

Dr. Donald Hasseltine

Vice President for Advancement

Colby-Sawyer College

100 Main Street

New London, NH 03257, USA

Phone: +1603 5263442

Email: dhasseltine@colby-sawyer.edu
}

\author{
Keywords: \\ capital campaign, fund raising, Virginia, \\ alumni, history of higher education
}

\section{Introduction}

Throughout the last century, campaigns have played a critical role for countless colleges and universities. They have allowed institutions to enrich the quality, quantity, and substance of academic and cocurricular programs, faculty development and research opportunities, and campus facilities. They have increased financial resiliency and, for some, even meant institutional survival. Once the domain of private colleges, campaigns now take place at virtually all types of colleges and universities, including community colleges. Public institutions have aggressively moved toward private fund raising to fill the budget gap created by decreasing state and federal spending on higher education, budget tightening and rapidly rising fixed costs (i.e. personnel). ${ }^{1}$ Private institutions need campaigns to find the resources to keep tuition and fees from rising too rapidly in an increasingly competitive marketplace. The escalating demand for institutionally provided 
financial aid also requires additional funding. These factors portend a future in which, for both public and private institutions, campaigning will only become increasingly important to organizations' future development.

As organized fund raising in higher education enters its second century, it seems appropriate to examine our future ambitions measured through the perspective of both the present and the past. The historian Michael Howard remarked that history provides a context to "... discover what we have been, understand what we are, and gain limitations of what we might become."2 A documentary analysis of the Centennial Campaign, the University of Virginia's first capital campaign in 1917, provides a historical perspective into the evolution of higher education fund raising, not only at the University of Virginia, but nationwide. Strategic components of effective capital campaigning which are assumed todaysuch as goal setting, the effect of national economic trends, the significance of the quiet or leadership phase, and the influence of institutional leadershipemerged during the period around the Centennial Campaign. These components provided lessons which the University has fruitfully applied in succeeding campaigns, demonstrated most effectively in its recently completed $\$ 1.4$ billion campaign.

Historically, private institutions have paved the way in higher education fund raising. Not surprisingly, Harvard, the original American college, conducted the first systematic effort to raise money in 1641. Three clergymen traveled to England to solicit money for the college. ${ }^{3}$ This year-long "begging appeal" produced a mere $£ 500$. Higher education forged through the Colonial and Antebellum periods conducting many more "begging" expeditions, bazaars, church suppers, and the writing of "begging letters." In spite of these primitive methods, at least 173 colleges produced enough revenue through enrollments and private support to remain open. ${ }^{4}$

Modern fund-raising methods were developed during the late 1800s and early 1900 s, when increasing wealth accumulation and puritan and democratic values began to spur the first wave of philanthropy in the United States. ${ }^{5}$ Charles Sumner Ward, a Dartmouth graduate, and Lyman Pierce, a University of Minnesota graduate, are widely recognized as the principal creators of the modern capital campaign. Their technique included "careful organization, picked volunteers spurred on by a team competition, prestige leaders, powerful publicity, a large gift to be matched by the public's donations, careful records, report meetings, and a definite time limit." Developed in the early 1900s, primarily to raise money for the Young Men's Christian Association (YMCA), this format caught the attention of the American Red Cross, hospitals, religious organizations, and institutions of higher education. Harvard University, The University of Pittsburgh, Elmira College, and Smith College were among the first institutions of higher education to use these new techniques.

Harvard's faculty salary campaign of 1904-5 introduced modern campaign techniques, and raised $\$ 2.5$ million. Harvard's Endowment Fund campaign of 1919 , which raised an unprecedented $\$ 14.2$ million in 18 months, swept organized giving onto the American higher education scene. The story of the University of Virginia's first capital 
campaign began shortly after Harvard's drive.

\section{The Centennial Fund}

Long before it completed the most prolific capital campaign for a public university, the University of Virginia had been a leader in both higher education and higher education fund raising. While the University's intellectual origins are well known, the foundation of the university's fund-raising success began, ironically, over 80 years ago with a campaign that by contemporary standards would have been deemed a failure. Quite simply, the campaign did not reach goal. This story is told through personal letters to the president and meeting minutes from the Board of Visitors (BOV), available in the University of Virginia Library in Special Collections. These documents examine campaign activity from a number of perspectives, including the Board of Visitors, the President, volunteer leadership, and paid professional staff.

The Canvasser's Handbook, the campaign training guide, captures the spirit of campaign intentions: "The three million dollar birthday gift which the University of Virginia's 10,000 sons plan for their Alma Mater upon the occasion of her 100th anniversary next June cannot be a reality unless you do your part."7

World War I caused a postponement of the Centennial Celebration plan. At a special Board of Visitors meeting on December 28, 1917, the faculty of the university adopted a formal resolution: Resolved, that the date of October 1919, be set for the Centennial Celebration; that the work of gathering materials, records, etc., be continued as actively as conditions will allow, and that the Centennial Celebration itself be postponed to such a time in the future as it may be feasible and possible to hold it. ${ }^{8}$

The planning commenced over two years later when President Edwin A. Alderman re-introduced the idea in a December 1919 letter to the Board of Visitors. He sent them two documents for their review: a document outlining the incorporation of an endowment fund through the Executive Committee of the Alumni Association, and a draft of the proposed legislation asking the state to allow the university to raise private funds while protecting its yearly appropriation.

Four responses from the Board of Visitors are preserved in Alderman's papers, showing varying degrees of support for the campaign. William White found the campaign effort "appealing ... [but] I cannot refrain from stating my belief that the proposed bill is impracticable." 10 Similarly, Eppa Hunton, Jr. stated: "In a general way, it seems to me the plan is impracticable and unwise."11 Chas Faulkner wrote a four-page response that commented on the confusing language, but did not offer an opinion about the viability of the campaign. ${ }^{12}$ Alex Humphrey voiced his support: "it would be a wise thing to attempt to get this additional endowment." ${ }^{13}$ Despite limited support from the Board of Visitors, Alderman and the rector John Stewart Bryan appear to have received some assurance from the John Price Jones Company and from the alumni leadership. (Note that the rector is the highest ranking officer and chairman of the Board of Visitors. The position is appointed by the governor of Virginia.)

President Alderman and the Board sought campaign counsel from the John Price Jones Company, the firm that handled Harvard's \$14.2 million 
endowment campaign, to evaluate the feasibility of the campaign and to provide advice regarding what organizational, budgetary, and operational considerations were necessary to run a campaign.

President Alderman in a letter dated June 9, 1920 to the Jones Company stated, "I have this day received the copy of the booklet which you prepared as a result of your visit ... It seems ... exceedingly illuminating and suggestive ...." 14 Comments from the case statement prepared by the Jones Company suggest that the Alumni Association Board of Managers were among the strongest supporters of the campaign. "The [campaign has] infinite appeal to alumni ... By reason of its early foundation and its primacy, ... the University has taken on a character, a tradition, a compelling allurement, to which we must seek counterparts in private, rather than state institutions." 15 These documents seem to indicate that Alderman was persuaded by the Jones Company and the support of alumni to continue pursuing the campaign, in spite of the less than enthusiastic response from the Board of Visitors.

President Alderman noted in the minutes of the January 27, 1920 meeting "that alumni and friends would not support such an endeavor without state assurance that creating an endowment will not reduce state support." ${ }^{16}$ Protecting campaign gift revenue from the state's influence was also of great concern. The University of Virginia Endowment Corporation was created as a separately incorporated nonprofit entity within the Alumni Association to protect the funds and to provide financial services, including gift processing and fund management. This entity gave the
University the autonomy to run the campaign.

In the Board of Visitors' meeting on January 27, 1920, a draft report on the endowment was presented by the Executive Committee of the General Alumni Association. The report outlined the proposed relationship between the Commonwealth of Virginia and the University of Virginia Endowment Corporation. Article IV of the draft proposal outlined the arrangement between the two parties:

... the Commonwealth agrees that its appropriations to the University of Virginia ... for current purposes shall never be less than the sum of the appropriations for current purposes ... in January 1920, plus such an amount as shall equal the annual income of the Endowment Corporation. ${ }^{17}$

Further, the Board of Visitors outlined the four planning stages of the campaign:

1. Preliminary: Secure certification of incorporation, Board of Visitors approval, and proper publicity;

2. Legislative: Secure passage of necessary legislation and approval by the Governor;

3. The Campaign: Get all alumni catalogued, creation of an organization in every state having a substantial number of alumni, followed by the actual solicitation process;

4. Administrative: Long term coordination and execution of endowment. ${ }^{18}$

The meeting minutes noted that persons with experience in Liberty Bond and Red Cross campaigns would be invaluable to the process. ${ }^{19}$ 
Planning stages one and two were completed by May of 1920, when the state legislature passed the bill approving the University of Virginia Endowment Campaign. Stage three, the Campaign, commenced shortly after the governor and legislature gave their approval. The organization of the Centennial Endowment Fund was confirmed on June 19, 1920 at the home of Rector John Stewart Bryan. Leaders attended the meeting from the faculty, alumni, and university administration. Armistead Dobie (graduated '04), a law professor, was named Executive Director of the campaign and Frederic W. Scott and Bryan were elected Joint and Alternative Chairman. ${ }^{20}$ The campaign objectives and goals, along with a timeline, were also confirmed at the meeting.

The University Centennial Celebration slated for June 1921 gave Dobie less than a year to assemble the organization to raise three million dollars. Dobie reported his progress to the Board in late July of 1921. "From July 12th to July 15th, I [have] spent at the University studying the standard plans used by other universities in raising endowment funds, in securing the necessary preliminary information and in preparing card catalogues of their alumni." ${ }^{21}$ He secured the services of Charles A. McKeand (graduated '13) to be his assistant by the end of July, and opened the Richmond campaign

headquarters in October. By November, he had formed an 11-member executive committee, designed a volunteer training weekend, recruited some 60 national and 45 regional chairmen, and completed a volunteer handbook and a campaign case statement. $^{22}$ Dobie's expeditious handling of the campaign infrastructure put the campaign on course.
On Thanksgiving Day 1920, the executive officers, national chairmen, regional chairmen, and a few local chairmen gathered to hear presentations from the president and deans about the institutional needs. ${ }^{23}$ Although it might have seemed a lot to ask of volunteers to meet on a holiday, a ticket to the North Carolina versus Virginia football game proved to be enough of an incentive to attract many interested parties. Volunteers received a handbook, a list of alumni to call, and other organizational materials. Among these was the Canvasser's Handbook, a 22-page pamphlet that contained the case statement, 19 reasons to give, the steps to follow in securing a gift, and a list of gift opportunities. It also suggested ways to reply to negative responses from alumni. During this organizational meeting, volunteers confirmed the primary campaign objectives, the campaign's executive committee, the publicity schedule, and the solicitation timeline.

The campaign objectives focused entirely on attracting endowment to support academic instruction and building construction. Alderman noted, "the university must in time be very universal in its reach and scope." 24 The objectives included attending to faculty salaries, which were "woefully inadequate" and to developing academic courses to meet the "proper conception" of the functions of a university. The campaign priorities and dollar goals were as follows: endowment for instruction included $\$ 850,000$ for immediate increase in salaries, $\$ 925,000$ for professorships and adjunct professors in various departments, and $\$ 50,000$ for graduate fellowships, for a total of $\$ 1,825,000$. Facility construction included $\$ 300,000$ for a memorial gymnasium and 
athletic field house, $\$ 200,000$ for dormitories, $\$ 175,000$ for the engineering building, and \$250,000 for a building for medical sciences, for a total of $\$ 925,000$. The remaining priority was a $\$ 250,000$ endowment for alumni activities. The campaign summary included endowment for instruction $\$ 1,825,000$, facility construction for $\$ 925,000$, endowment alumni activities for $\$ 250,000$. The total campaign objectives summed to $\$ 3,000,000 .^{25}$

The Campaign Executive Committee included seven alumni and four members of the Board of Visitors. From the campaign organizational guide, the Executive Committee members were identified as:

Joint and Alternative Chairman: John Stewart Bryan ('94) and Frederic W. Scott

Executive Director: Armistead M. Dobie ('04)

Executive Secretary: Charles A. McKeand ('13)

At-large members: John W. Craddock, Milton C. Elliott ('02), Julien H. Hill ('98), Homer L. Ferguson, Robert B. Tunstall ('02), Archibald R. Watson ('94). ${ }^{26}$

A determined national publicity effort was also part of the campaign planning process. Dobie credits Chas Trimmer, director of publicity, with getting 5,000 university clips regarding the campaign in national publications from October 1 , 1920 to June 8, 1921. Dobie recounted to the Board of Visitors that at least one fullpage monthly advertisement in the Richmond Daily Neres and eight consecutive months of special reports in the Alumni Newes were part of the publicity plan. In addition, all alumni received by mail a major pamphlet with "attractive illustrations and charts." 27

With less than six months until the Centennial Celebration, the campaign machinery was in place and ready for the solicitation phase to begin. The Campaign Executive Committee, however, faced a very sluggish United States economy. The Southern states were especially hard hit. As Dr. Hugh Young, the president of the Alumni Association, declared December 28 "the University of Virginia Night" and urged faculty, students, and fund representatives to spread the word about the campaign, the Campaign Executive Committee decided economic conditions warranted a postponement of the solicitation phase until at least March 7, $1921 .^{28}$

The campaign commenced in March as scheduled, leaving Dobie and his volunteer team just three months to raise $\$ 3$ million dollars. There is no record of the Board of Visitors and the Campaign Executive Committee discussing the impact of the adjustment to the goal or the extension of the time line. Dobie reported in late April that the campaign was off to a good start, having raised $\$ 694,804$ in the first two months of solicitations. Dobie also reported that he and the president had spent the previous month almost exclusively in New York City securing pledges. ${ }^{29}$ However, the file offers no mention of pending significant gifts.

A month later, the Alumni Neres headline read in bold capitals:

"Endowment Fund May Reach a Million By Centennial Celebration." ${ }^{30}$ From a report filed after the campaign, the Endowment Fund actually reached $\$ 1,074,990$ in pledges on May 30, one day 
before the beginning of the Centennial Celebration. ${ }^{31}$ Unfortunately, that was the best news about the campaign, as expectations were significantly greater.

The campaign ultimately stalled well short of its intended goal. Alderman addressed delegates and members of the graduating class on the final day of the Centennial Celebration, announcing gifts totaling $\$ 1.5$ million. "Of this sum, $\$ 1.3$ million is represented by the Centennial Endowment Fund, raised by an organization working under Armistead M. Dobie and functioning in forty-two regional districts throughout the country. The remaining $\$ 200,000$ was given by Paul Goodloe McIntyre ... to establish at the university a department of commerce and finance." 32

Dobie, in his final report to the Board of Visitors, placed the campaign tally at $\$ 1,304,330$. Of this amount, alumni were credited with giving $\$ 525,730$; nonalumni contributed $\$ 402,614$; and, perhaps most surprising, students pledged $\$ 144,380 .^{33}$ This was a point of considerable pride to all parties involved in the campaign. Dobie said, "it is believed that this was the finest bit of idealism in the entire movement. Too much credit cannot be given to the student body for their splendid service and sacrifice." ${ }^{34}$ The Alumni Magazine also praised the students: "The highlight remains that 1,440 out of 1,700 men contributed $\$ 146,000$." ${ }^{35}$ In contrast, alumni giving appeared to have been the biggest disappointment.

Based on the original goals, only Charlottesville and the district that included Arizona, New Mexico, and Utah reached their dollar quota. Despite Dobie and Alderman's time in New York, that district achieved only $\$ 251,585$ of a $\$ 660,000$ quota. ${ }^{36}$ Virginius Dabney, a
University of Virginia historian, wrote that the 1921 campaign "was a failure."37

According to Dabney, the alumni association had counted on the success of the campaign for future resources. Without those resources the association suffered a setback, including the loss of its talented executive director, Lewis D. Crenshaw, whose salary was in arrears when he resigned. ${ }^{38}$

Despite the early enthusiasm expressed by the alumni, Dabney reasoned that alumni apathy was the primary reason for the shortfall. Indeed, only 24 percent of alumni participated in the campaign. It is important to note, however, that with the same average gift, the alumni participation rate would have needed to rise to an unprecedented rate of 70 percent for the university to have achieved its $\$ 3$ million goal.

Dobie offered some other reasons for the shortfall. Most prominent in his mind was the economic depression across the United States. He described the situation as follows: "even men of large means, suffering from acute comparative psychological poverty, either refused to give or gave nominal sums." 39 Talk of coeducation, dissatisfaction with athletic policies and the prospect of moving the medical center to Richmond were other reasons cited by Dobie.

Dobie summed up his experience in his last written report to the Board of Visitors:

While the task of raising money is essentially unpleasant, and while it is very trying on the nervous system to run a great enterprise, with volunteer aides, in distant cities, who work without pay and who cannot be severely criticized, yet, in the language of President Alderman, I count any service 
to the University of Virginia, which it is my pride and privilege to serve. ${ }^{40}$

Dobie, unfortunately, thought his efforts had not accomplished very much for his alma mater. However, he may have underestimated his work.

In retrospect, the dollars raised for the campaign provided a much more significant financial boost to the university than history would have suggested. If the outcome of the campaign is measured as a ratio of the budget and state appropriation of that time, the $\$ 1.3$ million raised in the Centennial Campaign was three times the 1921 university budget of $\$ 431,145$ and 13 times the state appropriation. ${ }^{41}$ By comparison, the recently completed \$1.4 billion goal is just nine times the yearly state appropriation of $\$ 119$ million and only equal to the size of the 2000 annual operating budget of just over a billion dollars. $^{42}$ Ironically, the $\$ 1.3$ million raised for the Centennial Campaign provided considerably more spending power than the enormously successful $\$ 1.4$ billion campaign recently completed at the University of Virginia.

More impressive was the fact that $\$ 1.3$ million was raised in three months. Dabney writes that $\$ 1,037,851$ had been collected from all sources by 1928 , an overall pledge fulfillment rate of 80 percent. ${ }^{43}$ Furthermore, the campaign cost was $\$ 28,508$, approximately 2.2 cents per dollar raised. Considering that the University had never had a campaign before, the Centennial Campaign costs were reasonable by even current standards. By all of these measures, the Centennial Campaign was a success.

The campaign may have suffered from unfortunate economic timing, inexperience, and poor goal setting, but it produced significant resources to advance the mission of the University. A decade later, the Centennial Campaign's impact was more fully appreciated by one of its original leaders. Robert B. Tunstall, the alumni treasurer of the Endowment Fund, stated: "the fund rendered possible the erection of the gymnasium, of the orthopedic and obstetrical wing of the hospital and the completion of the new medical group of buildings; and the income from it has been, and is being, of help to the university in a variety of important ways." 44 The campaign demonstrated however, that there was still more to learn about effective capital campaigning.

\section{Lessons from the Past}

Despite the fact that the Centennial Campaign raised over one million dollars, the most ever by the university, it was viewed as a failure. The Centennial Campaign offers a case where an institution made a strategic error in not reevaluating the goal when it became clear that the economic environment was not favorable. The leadership may have allowed the University's Centennial Celebration to drive the conclusion of the campaign; however, the president and campaign leadership had three months between December 1920 and March 1921 to strategize and develop an attainable and appropriate solicitation schedule. They failed to recognize the impact of their inaction on the institution. The influence of external environmental factors on a capital campaign, such as the economy or war, requires careful assessment by the institution's leadership. Their primary goal needs to be protecting the integrity and image of the institution. 
This is an important reminder that campaigns make institutions fully accountable for their objectives. The failure to achieve the intended goal may not only have institutional consequences, but may also affect how constituent groups perceive the institution. In an era of billion dollar campaigns, it is possible to get caught up in chasing another institution's dream, while failing to examine one's own constituency for its potential. Institutions need to be diligent in evaluating their internal and external environments, as well as honestly assessing potential donor capacity.

Campaign methodology used in 1921 resembles modern techniques in many ways. The practice of setting priorities, creating a regional volunteer structure, establishing a campaign executive committee, and seeking campaign counsel are still employed in current campaigns. Perhaps the most significant methodological change in the last century has been in the length of time allotted to the campaign process. Pierce and Lyman found that limiting the campaign solicitation process to no longer than a year, with a three-to-six month solicitation period, was necessary to create the sense of urgency required to motivate volunteers, the media, institutional leadership and, most importantly, potential donors. This approach, however, used primarily with nonprofits with a constituent base located in a small geographic location, such as a city YMCA, proved challenging for a broader based effort. The Centennial Campaign demonstrated that geographic breadth could make such a limited time frame extremely difficult, especially during times when communication was limited to mail and underdeveloped phone systems.
The Centennial Campaign would have benefited from a longer leadership gift phase to obtain important lead gifts and create momentum for the campaign. This example reemphasizes how important the leadership gift phase is to successful campaigning. Running the entire solicitation phase in three months is unimaginable in current campaign methodology. The important lesson from this example, however, is how the leadership gift phase allows the securing of significant gifts from trustees and close friends, provides the opportunity to assess donor interest, and assesses the overall capacity of the donor base. The leadership gift phase provides real-time market data to support the campaign goal.

Viewing the first capital campaign of the University of Virginia from a distance of more than 80 years provides reassurance that modern campaign techniques are grounded in firm principles and techniques based on lessons of the past. As the nonprofit sector continues to grow and new demands are placed on available philanthropy, however; higher education must continue to evolve its approach to campaign fund raising. In The Customer Century, Gronstedt claims this new century will require a focus on customization, personalization, convenience, and speed. ${ }^{45}$ Campaign success will depend on institutions being able to create systems that manage a wide range of relationships in more personal and meaningful ways. This will require the adoption of best practices from industries outside of higher education. When historians look back on higher education in the twenty-first century, may they find the same unprecedented levels of success that higher education enjoyed during the twentieth century. 


\section{References}

1. K.E. Dove (2000), Conducting a Successful Capital Campaign, Jossey-Bass, San Francisco, pp. 6-7.

2. M. Howard (1991), The Lessons of History, Clarendon Press, Oxford, p. 199.

3. S. M. Cutlip (1965), Fund Raising in the United States, Rutgers University Press, New Brunswick, NJ, p. 3.

4. R. L. Church and M. W. Sedlak (1989), "The Antebellum College and Academy," in L. F. Goodchild. and H. S. Wechsler (Eds.), ASHE Reader on The History of Higher Education, Simon and Schuster, Needham, MA., p. 102.

5. Cutlip (1965), Fund Raising in the United States, op. cit. p. 44.

6. Ibid, p. 44.

7. Ibid, p. 1.

8. BOV minutes (1920), vol. X, part I, University of Virginia Archives, p. 97.

9. Ibid

10. E. A. Alderman (1920), President's Papers, William White letter to Alderman, January 27, University of Virginia Archives, general file: fund raising.

11. E. A. Alderman (1920), President's Papers, Eppa Hunter letter to Alderman, January 28, University of Virginia Archives, general file: fund raising.

12. E. A. Alderman. (1920), President's Papers, Chas Faulkner letter to Alderman, February 11, University of Virginia Archives, general file: fund raising.

13. E. A. Alderman (1920), President's Papers, Alex Humphrey letter to Alderman, February 5, University of Virginia Archives, general file: fund raising.

14. E. A. Alderman (1920), President's Papers, letter to John Price Jones, June 9, University of Virginia Archives, general file: fund raising.

15. E. A. Alderman (1920), President's Papers, BOV docket, January 27, University of Virginia Archives, general file: fund raising, p. 3 .

16. Ibid.

17. Ibid.

18. E. A. Alderman (1920), President's Papers, BOV file, University of Virginia Archives, general file: fund raising, p. 9.

19. E. A. Alderman (1920), President's Papers, BOV docket, January 27, University of Virginia Archives, general file: fund raising.

20. BOV minutes (1920), vol. IX, part II, University of Virginia Archives, pp. 226-30.

21. Ibid, p. 226.
22. E. A. Alderman (1921), A Standard Plan of Organization for the University of Virginia Centennial Endowment Fund, University of Virginia Archives: Centennial Celebration printed material file.

23. BOV minutes (1920), vol. IX, part II, University of Virginia Archives, p. 227.

24. E. A. Alderman (1920), President's Papers, BOV docket, January 27, University of Virginia Archives, general file: fund raising, pp. 2-3.

25. Ibid.

26. E. A. Alderman (1921), President's Papers, A Standard Plan of Organization for the University of Virginia Centennial Endowment Fund, University of Virginia Archives: Centennial Celebration printed material file.

27. BOV minutes (1920), vol. IX, part II, University of Virginia Archives, p. 228.

28. Ibid, p. 227.

29. Ibid, p. 228.

30. Alumni Neres (1921), vol. IX, May, no.10, pp. 219-21.

31. BOV minutes (1920), vol. IX, part II, University of Virginia Archives, p. 228.

32. New York Evening Post (1921), June 4.

33. BOV minutes (1920), vol. IX, part II, University of Virginia Archives, p. 228.

34. Ibid, p. 227.

35. Alumni Neres (1921), vol. IX, May, no.10, p. 220.

36. Ibid.

37. V. Dabney (1983), Far Echoes from the Old Arcade: A History of the Alumni Association, University of Virginia Alumni Association, University Press of Virginia, Charlottesville, VA, p. 17.

38. Ibid.

39. BOV minutes (1920), vol. IX, part II, University of Virginia Archives, p. 229.

40. Ibid, p. 230.

41. E. A. Alderman (1921), President's Papers, Canvasser's Handbook, University of Virginia Archives: Centennial Celebration printed material file, p. 3.

42. University of Virginia (2002 February 14) http:// www.virginia.edu/budget/summary2001.pdfUVA budget information.

43. V. Dabney (1981), Mr. Jefferson's University: A History, University of Virginia Press, p. 64.

44. Ibid, p. 66.

45. A. Gronstedt (2000), The Customer Century, Routledge, New York. 


\section{Practitioner's Perspective}

Practitioners in development tend to believe that the capital campaign is a relatively new concept, particularly for public institutions. We hear about the "modern" capital campaign experience or the "new era" of campaigns, which usually means that they involve significant planning, prospect research, goal-setting, and use of volunteers, and that they represent a comprehensive effort, have a focus on major gift fund raising, and involve a significant public education and relations effort. What a surprise to learn that at least at this public institution, the University of Virginia (UVA), the first capital campaign began in 1917. And, that without the benefit of electronic screening, computers, or even a "development officer" as we know the term today, university leaders, alumni, and friends managed to incorporate most of the elements we now consider to be "best practices" for capital campaigns. Not only did the leaders of the Centennial Campaign look to a benchmark institution for aspiration and guidance, but they employed techniques that today would be listed under "best practices" for capital campaigns, namely a significant planning period that involved alumni, friends, faculty, and members of the administration; a feasibility study; the use of campaign counsel; a leadership gifts phase; a regional program; a volunteer structure; and an end date related to a significant event in a university's history. Except-the Campaign failed to meet its goal.

Lest we become victims of history repeating itself, are there lessons to be learned from the early part of the last century that can help our fund-raising efforts today? I think so, except that our learning process seems to resemble "continuing education" more than a one-time lesson. As marketing professionals for our institutions, our natural inclination may be to discount the lack of enthusiasm by our leadership for our "case," despite our consultant's evidence to the contrary; or to move ahead with a public phase when the goal of the nucleus fund has not been achieved; or seek to move ahead aggressively or perhaps postpone a campaign when faced with war or a sluggish economy. The terms used then to describe prospective donors as those suffering "acute comparative psychological poverty" could not be truer today. Despite evidence to the contrary, we appear to have learned one lesson well: "Create the plan. Work the plan." The fact that the plan may need to be changed to accommodate changing conditions seems to be missing from the "best practices" handbook.

However, over the years, whether by necessity or through quantitative analysis, we have come to learn quite a bit about the economics of a fund-raising campaign. Using the newspaper and alumni magazine as the primary marketing strategies, as in the Centennial Campaign, has been replaced by target marketing that relies on the gift pyramid and personalized cultivation and solicitation techniques. While the 2.2 cents per dollar raised (about 12.3 cents in today's dollars) may seem enviable today, it seems likely that if it had been possible to employ target marketing in the Centennial Campaign, the result might have been very different. 
Our public institutions continue to wrestle with the same issues that UVA faced nearly a century ago. Will a successful campaign mean reduced state support? How can campaign gift revenue (and now donors) be protected from the state's influence? How important is participation percentage when alumni records exceed 100,000 and when the pressure exists to grow endowment and increase faculty support in an era of declining state support?

The research on the Centennial Campaign helps this practitioner to conclude that, as a profession, we continue to "practice" the art and science of managing capital campaigns. The author makes a valid point that in this era of billion dollar capital campaigns, we must focus on our institution's unique constituencies and potential rather than "chasing another institution's dream." It may also mean that we will have to begin to define success differently.

Elizabeth A. Flanagan, Ph.D., CFP Vice President, Development and Alumni Relations Virginia Tech, Blacksburg, VA, USA 